\title{
Behavioral Patterns and Genesis of a Polymorphous Paraphilic Serial Killer
}

\author{
Paola Giannetakis* \\ Link Campus University, Italy \\ Submission: October 27, 2017; Published: November 13, 2017 \\ *Corresponding author: Paola Giannetakis, Link Campus University, Italy, Email: p.giannetakis@unilink.it
}

\begin{abstract}
Polymorphic paraphilic spectrum defines the psychological and behavioral dimension of serial murder. Clinically subject displayed traits of antisocial personality disorder and NOS personality disorder, genesis and development of behavior is analyzed using a multi-perspective approach.
\end{abstract}

Keywords: Paraphilic disorder; Behavioral patterns; Serial killing

\section{Introduction}

\section{Childhood and Adolescence}

Jeffrey Dahmer was born on May 21, 1960, in Milwaukee; his parents were Lionel and Joyce Dahmer. Joyce's father was severely alcoholic and he was distant and uninvolved with her. Joyce had problems during her pregnancy and started taking drugs to treat her sickness. After Dahmer was born he had problems with his legs and was immobilized until the child was four months old. Despite this problem, he seemed to grow up as a healthy beautiful child, his achievement was of his age, but at one point his mother started to refuse to breast feed him. Joyce was showing an unstable behavior, continuously lamenting for neighbor's noises, needing to be constantly reinsured from her husband. Since she could not tolerate such stimulations, she increased the consumption of antidepressant.

The couple moved six times in their first years of marriage. In 1962, the family moved in Iowa. Lionel had been accepted to a doctoral program in chemistry; in this period Jeffrey Dahmer got sick very often and required several injections to treat infections. When he started to go to preschool, he resulted as being very shy, while his interest in insects and animals was starting to take form, he, in facts, helped his father in nursing a owl they found and then other several animals. When Jeffrey Dahmer was four, his father found some dead animals in decomposition and the child touched the bones and broke them into pieces. He liked to play with small bones; it was a thrilling experience to him. His father was almost absent, due to his career, and did not spent any time with his son who was beginning to show to be shy and was avoiding those activities usually children love, such as those characterized by physical contacts and competition. At the age of six Jeffrey Dahmer undergone hernia surgery, when he woke up from the anesthesia he was worried someone had cut his genitals, after a long recovery period his parents remember he turned to be very loner. His mother's depression was increasing and so was her consumption of antidepressants. The atmosphere at Dahmer's home was characterized by continuous litigations and quarrels between the parents [1-3].

When he started to go to school, he was terrified and avoidant, his teacher told his parents that he was not interested in schoolwork and that he was very shy. Dahmer was growing more and more isolated, lacking significant parental figures, his father was too involved in his activities, and his mother was suffering from serious psychological problems. Dahmer showed a low tolerance to frustration, probably as his mother, but on the contrary of her, did not externalize, rather he was showing nothing more than silence; his coping skills were limited to go walking in the woods or exploring animal's interiors. Arguments between his parents worsened. The disease of his mother and the conflicts within the family reached a critical level, until his mother was sent to a neuropsychiatry structure for one month. Some experts hypothesized that Dahmer felt guilty for his mother sickness; that he thought to be the cause of all the problems in his family and for this reason had a precocious alienation from his family. This apathy was evident as was his internal suffering, but he was never able to communicate such feelings.

In coming years, during high school he was considered a strange boy, reserved, showing bizarre behaviors, in these years he started to drink, he used to go to school with a scotch bottle. 
One day in 1975 some guys from the neighborhood walked behind of his house and found the head of a dog impaled on a stick and the body of the animal skinned attached to a tree. Dahmer although was very obsessed with animal's bodies, never killed an animal, he was not interested in their suffering, rather preferred to collect dead animals [4]. He was not excited by inflicting pain to living creatures but in dismembering the bodies. In 1978, during the last year of school marriage of his parents ended. Few weeks after being abandoned by his mother, Jeffrey Dahmer gave an auto stop to a nineteen-year-old named Steven Hicks and invited him home. The two men drank some beer, chatted and had sex. When Hicks said, he had to get back on travel; Dahmer smashed his skull and strangled him. He later dismembered his body and put pieces into plastic bags. He was eighteen.

He enrolled at Ohio State University and for a while he tried to attend, but only after few months he abandoned his studies and joined the army. To his comrades, he seemed like a normal boy until he began to drink, showing a very different mood, aggressive and arrogant. Although he signed for six years, the Army dismissed him after two. He went to live with his grandmother and found work at a donation center. In 1985, he was hired as a laborer in Ambrosia Chocolate Company [5].

\section{Killings}

That same year, something else happened. Something decisive and terrible, his disease, remained dormant for almost six years, came back. One night, with an occasional companion, took a room at the Ambassador Hotel. The two men drank, had sex and then fell asleep. When Dahmer wakened the next morning, the other man was dead and the blood dripped from his mouth. From this point on, he stopped fighting his instincts, he gave up and killed again, another homosexual met in a bar and brought to his grandmother's house. Dahmer kept his victim's skull as a souvenir after having cleaned all traces.

In the subsequent years, Dahmer had several problems with the law. In 1986, he was arrested for indecent conduct after urinating in front of some children. Two years later, for luring a boy of thirteen, he took him in his apartment in Milwaukee, gave him a drink with a sedative and sexually molested him [6]. He was arrested with a second-degree charge for sexual assault and enticement of minors with an immoral intent; he spent ten months in prison before being released in May 1990.

Over the next year, Dahmer murdered three other men. At one point the neighbors noticed the nauseating smell coming from his apartment, but when they knocked on his door to protest, he successfully managed the situation explaining that the freezer was broken and the meat had gone bad. His gentle manner was so convincing that the neighbors believed him. In May 1991, was about to be discovered. Shortly after the midnight on 27, two women saw Dahmer chasing a teenager on the street naked and bleeding. They called the police, but Dahmer could escape thanks to his power of persuasion. He convinced the agents that he and the boy were lovers engaged in a harmless quarrel. The police went away, leaving the boy stunned in the control of Dahmer. Later, what remained of the boy was found with the other human remains in Dahmer's house.

In the two months that followed, Dahmer had five other victims.

Late July 1991, two Milwaukee police officers saw a man staggering towards them with a pair of handcuffs in his wrists. He was gesticulating to stop the car, the man pointed to Dahmer's home and told a confused story of a white blonde man who wanted to kill and eat him. The officers went to control and discovered the chamber of horrors of Dahmer. The drawer of the bedroom was filled with Polaroid's of pieces of human bodies and mutilated bodies; in the freezer, they found three human heads a several organs: intestines, lungs, livers, kidneys and heart. Dahmer told police he had put aside the heart "to eat it later". Another head was kept in the refrigerator, seven skulls and five complete skeletons were conserved in different points of the apartment, and they also found sexual organs in a pot, bottles of acid, chloroform and formaldehyde. And all these gruesome trophies were the remains of eleven victims.

\section{Serial Killer}

"Cases of serial killing share commonalities and characteristics; anger low self-esteem, fantasy, facilitation, and objectification of the victims are all common denominators in understanding the etiological rules of serial murder" Hichey 2010. According to Hickey, Dahmer can be categorized as a Hedonistic serial killer, and a lust murderer Holmes and Holmes 2009, his killings involved sex with the victims often post mortem [7]. His actions evidence both elements of organized and non-organized offender Ressler 1988. Ressler classified Dahmer as an organized offender, premeditating his actions, convincing victims to follow him in his home, take advantage of them and dispose of their bodies; he also exhibited patterns of disorganized offenders. He labelled him as mix offender Ressler 1992.

He showed a planning of actions pre-and post-attack. Crime represented the climax of an elaborate erotic sexual fantasy. Victims were unknown, between a crime and the other he had periods of remission that proportionally decreased, the last killings had shorter interval one from the other. He had some type of resistance at the early stage; six years passed from his first victim to the second. Which is typical of serial killing? He did not have any moral sense to block him or it was too weak to inhibit his desire, victims were considered inanimate objects or inferior and he did not proved remorse. It is obvious that he had extremely aberrant sexual behavior. The way in which he grown up made him unable to experience something that even vaguely resembled to love and affection. His personality as his behavior is polymorphic [8-10]. 


\section{Modus Operandi and Signature}

The MO includes techniques to commit the crime, these techniques may evolve and change, Dahmer's MO was simple, his first objective was to bring home the victim he had chosen, he used to meet possible victims at a gay bar and offer free alcohol and money to shot naked photographs or tell he wanted to make a porn movie. Once alone, he would drug them, and kill them. Most of victims were strangled. Signatures are usually actions not necessary to achieve death. Mutilations can be considered as paraphilic footprints, extensions of paraphilic fantasies they help offender in realizing his fantasies. Post mortem dismemberment can be considered a signature. Dahmer collected trophies (body parts) and souvenirs (pictures) all those were later used for sexual arousal. After the victim death, he could masturbate over the body or have sex with the body, both by sodomization but also penetrating the viscera with his penis. Then he dismembered the body and dispose of remains according to a project he designed in his mind. He kept parts of the bodies including the skulls, and often-refrigerated organs, which were lately eaten. He worked with several substances to clean the bones from the meat. Dahmer desired to have someone passively at his disposition. He considered himself to be unable to build a relationship he preferred a passive partner. Killing allowed him to keep the person with him. Indeed, he was trying to dehumanize the person infiltrating substances in his brain [11]. He fantasized over creating a slave, a kind of zombie, who could sexually satisfy him and stay with him. He ended up killing his victims but keeping them with him by collecting their flesh and bones and sometime parts of genitals. He was searching some passive sex with someone or better with something.

\section{Fantasies, Paraphilic Disorder and Homosexuality}

Hickey 2010 writes that "fantasies can be reinforced by powerful sex drives that facilitate unusual behaviors" Sexual murder is based on fantasies Ressler 1998 fantasy is to take control of the victim; take control is something that Dahmer has sought since childhood. Dahmer as a child was thrilled by interiors of animals, at one point the animal was not enough and during his puberty his fantasies started to be focused on the body of a male, he had few intercourses with a friend, but later he started to prefer a body of an athletic man that should stay immovable as dead, he had fantasies of possessing a body not of loving another person [12]. Especially he used to concentrate over the abdomen. DSM-5 defines paraphilia as "any intense and persistent sexual interest other than sexual interest in genital stimulation or preparatory fondling with phenotypically normal, physically mature, consenting human partners" when a paraphilia "causes distress or impairment to the individual or if its satisfaction entails personal harm (or the risk of such harm) to others, it is considered a paraphilic disorder".

To determine the presence of a paraphilic disorder DSM-5 requires that subject: Feel personal distress about their interest, not merely distress resulting from society's disapproval; Or Have a sexual desire or behavior that involves another person's psychological distress, injury, Or Death, or a desire for sexual behaviors involving unwilling persons or persons unable to give legal consent.

Paraphilic disorders are diagnosed in forensic settings most of times and are show a strong correlation with criminal offenses, Diagnostic and Statistical Manual of Mental Disorders, Fifth Edition (DSM-5), lists the following 8 specific paraphilic disorders
a) Voyeuristic disorder
b) Exhibitionistic disorder
c) Frotteuristic disorder
d) Sexual masochism disorder
e) Sexual sadism disorder
f) Pedophilic disorder
g) Fetishistic disorder
h) Transvestic disorder

Other paraphilias include (but are not limited to) the following:
a) Telephone scatologia
b) Necrophilia
c) Partialism
d) Zoophilia
e) Coprophilia
f) Klismaphilia
g) Urophilia
h) Autogynephilia
i) Asphyxiophilia
j) Video voyeurism
k) Infantophilia

Including type I, inhibited flaccid exposer, and type II, sociopathic exposer is not rare to suffer of more than one paraphilia. Paraphilic cannibalism is used to describe a person who gains sexual pleasure from consuming human flesh. Dahmer admitted of having eaten only the meat of one of his victims, however in an interview he clearly admitted he used to eat their flesh as it was a way to keep them with him and because this gave him a kind of sexual excitement. Dahmer A\&E documentary.

Dahmer seemed to enjoy the dismembering of the bodies and used to take pictures of body parts. According to Hickey is a souvenir that many serial killer do collect in order to remember 
victims and pleasure derived from their crime Hickey 2010. Dahmer was suffering of necrofetishism, he was fetishist of dead bodies and kept dead bodies in his home and slept with them. Human surrogates functional to his fantasies. In the evolution of his fantasy he would rather prefer living bodies [13-15].

Necrophilic homicide is when someone kills another person to get his body for sexual pleasure. This type of offender also defined as necrosadist include partialism, collecting of specific parts of the body, and defined cannibal when eats body parts to keep the victims with him Hickey 2010. Having sex with dead corpses, with viscera can be also seen a denial of his homosexuality, Dahmer expressed blame into his victims, instead of hating himself. Palermo, during the trial, concluded that these murders were the result of an unconscious hate of his victims, that these murders were the result of his ambiguous homosexuality. Pedophilia is also considered as one type of paraphilia, Dahmer was arrested for molesting children, for exhibitionism and obscene acts in front of them. In conjunction with this, most of his victims were young. Dahmer's father said Dahmer was sexually molested at the age of eight. According to Holmes' classification; Inadequate Pedophiles search for children because they feel weak and unable, they feel to be better managing the situation with a child. Sadist child molesters are more likely to focus on young boys and to be fatal to them. They also can mutilate bodies and are often considered antisocial and sociopaths. Dahmer showed characteristics pertaining to both these child molesters. At the time of the charges, three psychologists examined him and described him as angry, evasive, and manipulative.

\section{Psychological Profile}

Wahlstrom, a psychiatrist, who provided a diagnosis during the trial, described Dahmer was a psychotic, a man suffering from long time of a mental illness never cured for. His fantasies about creating a zombie were clear evidence of these hallucinating beliefs. Palermo testified in court and provided a picture of Dahmer as being a sadist maniac, aggressiveness and anger feelings pushed him to kill; sexual desire was only a vehicle for these feelings to be externalized. As Dahmer was considered unable to build any kind of relationship, this frustration grew up and ended as anger and hate. He killed those men because he wanted to destroy the attraction he had for them. He could such destroy the part of himself he hated most.

Dietz, described Dahmer as premeditating with attention his crimes. Organized offender who lured victims during weekends, preparing his sedative powders to add them into this victim's cocktail. Dahmer was always empowering himself with alcohol because otherwise he would not be able to kill. A Paraphilic but not a sadist since he tried to avoid sufferings to his victims [16].

\section{Family's Dynamics}

Dahmer's mother was psychologically disturbed and his father mostly absent. Anders studied relations' disturbance during infancy, he classified relational disorders as those situations in which the relation between child and caregiver have distorted interactional models, these are difficult to be modified and lead to regulation disorders in children. A balanced relationship between caregiver and child is based on synchronicity and reciprocity, a mother who suddenly refuse to provide his child with breast feeding is alike a mother who refuse to hold physically the child. When the dyad is maladjusted a series of disorders in children may develop. The Feeding scale is a measure that analyses feeding styles and behavior of the mother in the nurturing; show that when children and mother have maladaptive feeding patterns children are more likely to be distant from mutual involvement. The Still Face Paradigm is a tool that evidences how children of 6 months can recognize their mother's depression.

They are less likely to react to stressors, because already over stimulated on this sense [17]. Dahmer's apathy and avoidant behavior could be a result of his mother being clearly disturbed herself. Measuring the impact on Dahmer development is difficult but should be taken in consideration. Environment in which he grew up can be considered as characterized by several risk factors on developing psychological related impairments. Dahmer also feared to be alone. After his parents divorced he was left alone from his mother without food, he was immature and his father found him after two weeks in a total mess. In these two weeks alone he killed his first victim.

\section{Psychodynamic Contribute}

Dahmer grew up conditioned by the association of death with pleasure, he started with an excitement for internal bodies of animals and later in puberty viscera and bones became the object of his sexual compulsions. The heat produced by pieces of body was sexually arousing to him Schwartz 1992. Normally, children focus their primary sexual interests toward their opposite sex parent, they later gradually move toward one of their peers. This is known as oedipal stage. According to psychodynamic theories, children who do not healthy resolve the oedipal conflict are more likely to suffer of psychological disorders. In Jeffrey Dahmer maladjusted development, his libido was focused on visceral, organs and bones, because he lacked the competence to link to his peers. The genesis of fetishism is characterized by desires directed toward unusual objects or situations. He could achieve satisfaction and sexual gratification only in presence of determinant stimuli.

\section{Motivational Model}

Motivational model developed by Burgess 1986, includes an essential formative dimension within the family, a not affective social dimension and lack of bonds contribute to a child's negative perception of reality, this influence cognitive thoughts processes including sexuality Ressler, Burgess and Douglas 1988. Dahmer's lack of bonding with his parents was the main cause of his inability to cultivate relationships in the appropriate way. Trauma, development failure and interpersonal breakdown. All 
these influence the cognitive mapping processing which is the base for the structure of sexual fantasies.

\section{Social Incompetence}

His father said that as a young child Dahmer avoided eye contact, he exhibited difficulties in interaction with other children and seemed to be emotionally distant Masters 1993. Dahmer was lacking social skills; he did not know how to handle relations with others. Despite this evident difficulty no concrete intervention was offered to him. Dahmer inability to build relationships, worsened after his adolescence, as a young adult he did not had friends, his homosexual encounters never tied him in a relationship. He was not close with his parents. He was alone with his fantasies.

Schizoid disorder of personality is characterized by "A lack of interest in social relationships, a tendency towards a solitary lifestyle, secretiveness, and emotional coldness". Behavioral patterns are similar in autistic children; a functioning type of autism is represented in Asperger's syndrome of which some scholars believe he was suffering. Dahmer's isolation from his peers and lack of normalizing effect peers may produce could have empowered his abnormal fantasies. Dahmer's lack of social skills was evident he was unable to tie with others and in this sick development he substituted partners with corpses [18-19].

\section{Sadism and Control}

Sadistic pleasure is not achieved only inflicting pain. It also has much to do with the assertion of power, the desire to dominate, to reduce a victim in a state of total submission. Some psychiatrist defined Dahmer as a sadist others did not. What is known is that even if he used Halcyon to sedate his victims, he did tremendous mutilations of their body's, dead or alive, the use of sedation, according to the author, rebalanced his sense of inferiority and insecurity; he simply felt unable to overwhelm them. Psychological reasons for sadism could be identified as the result of psychological suffering, he grew up considering himself of poor value and, as a defense mechanism, his self-esteem and self-concept were diminished and tended to attribute others the same poor consideration. This belief facilitates dehumanization. To overcome the sense of impotence he took control over another human being.

In the most extreme fantasy realization he tried to create a slave, transforming a man into a completely passive object, like a doll that could belong to him entirely. He was incapable of normal human relations with consenting partners so sought gratification with inanimate bodies, which could not have opposed resistance. The dehumanization process was materialized; he did not need more than a body without a soul, deprived of any human emotion and will. Some argued that he avoided suffering in his victims sedating them; truth is that the excitement he had was deriving from the control on their bodies rather than killing itself. He lucidly and rationally managed himself to obtain what he desired.

\section{Depression and Alcohol Dependence}

Dahmer seemed a depressed individual since his childhood; his brother reported he never smiled. He had no interest in his age' typical activities and his emotions were flattened. Dahmer had a long history of abuse of alcohol he used to drink during classes, he was required to detoxify from it but never really succeeded, and indeed he was later discharged from the Army for alcohol abuse Masters 1993. Paraphilic disorders are comorbid with alcohol abuse and with depression: alcohol is used as a self-medication; it helps the individual to lower or avoid painful emotions. Alcohol helps the paraphilic to increase dis inhbition and to engage in heinous actions that he could possibly feel unable to commit when sober. Dahmer had to drink to murder his victims, since he did not like to kill $[20,21]$.

\section{Discussion}

His behavior, a mirror of a personality that we can define at the boundary between the antisocial disorders of personality and not otherwise specified personality disorder, highlights the lack of moral constraints and boundaries. A strong relationship between the pattern of personality detected, the sexual sphere and the manifested criminal modality reveal a polymorphic profile. He lived between delirium and rationality, being concrete and detached at the same time. Nature and nurture contributed to the development of his personality, his sexual arousal generated around abnormal fantasies a product of his inability of normally relate to others. He wanted to control completely his victims, choosing them, killing them, and eating them that sense of control he missed in his life.

\section{References}

1. Carlin N (2011) Confession and Forgiveness A Pastoral Reading of A Father's Son by Lionel Dahmer. Pastoral Psychology 60(3): 377-397.

2. Culhane SE, Hilstad, SM Freng A, Gray MJ (2011) Self-reported psychopathology in a convicted serial killer. Journal of Investigative Psychology and Offender Profiling 8(1): 1-21.

3. Hare RD (1965) Acquisition and generalization of conditioned-fear response in psychopathic and non-psychopathic criminals. Journal of Psychology 59: 367-370.

4. Hare RD (1991) The Hare psychopathy checklist-revised. Toronto: Multi-Health Systems.

5. Hare RD, Harpur TJ, Hakstian AR, Forth AE, Hart SD, et al. (1990) The revised Psychopathy Checklist: Reliability and factor structure. Psychological Assessment 2(3): 338 -341.

6. Henson JR, Olson LN (2010) The Monster Within: How Male Serial Killers Discursively Manage Their Stigmatized Identities. Communication Quarterly 58(3): 341-364.

7. Hickey EW (2010) Serial murderers and their victims. Belmont Ca Wadsworth

8. Lilienfeld KA, Fowler (2006) The self-report assessment of psychopathy: Problems, pitfalls, and promises. In CJ Patrick Editor Handbook of psychopathy Guilford Press, New York, USA, pp. 107-132.

9. Lilienfeld MR Widows (2005) Manual for the Psychopathic Personality Inventory-Revised (PPI-R), Psychological Assessment Resources, Lutz, Florida, USA. 
10. D Lykken (1995) The antisocial personalities, Lawrence Erlbaum Associates, Hillsdale, New Jersey, USA.

11. Masters, Brian (1993) The Shrine of Jeffrey Dahmer. Hodder and Stoughton, London.

12. Palermo GB (2008) Narcissism, sadism, and loneliness: The case of serial killer Jeffrey Dahmer. In R N Kocsis (Eds.), Serial murder and the psychology of violent crimes, Totowa, Humana Press, New Jersey, USA p. $85-100$

13. Pardue A, Arrigo BA (2008) Power, Anger, and Sadistic Rapists: Toward a Differentiated Model of Offender Personality. International Journal of Offender Therapy and Comparative Criminology 52(4): 378-400.

14. Patrick CJ (2006) Handbook of psychopathy. Guilford, New York, USA.

15. Patrick CJ (2010) Operationalizing the triarchic model of psychopathy Brief scales for assessment of boldness, meanness, and disinhibition Paper presented at the American Psychology-Law Society Annual Conference, Vancouver, British Columbia, Canada.

This work is licensed under Creative Commons Attribution 4.0 License DOI: $10.19080 / J F S C I .2017 .05 .555683$
16. Patrick EM, Bernat (2009) Neurobiology of psychopathy: A twoprocess theory. In GG Berntson and JT Cacioppo, Editors, Handbook of neuroscience for the behavioral sciences, Wiley, New York, USA.

17. Ressler, Robert, Shachtman, Tom, Yaakov, et al. (1992) who ever fight the monsters. Hw Wilson Co.

18. Silva JA, Ferrari MM, Leong GB (2002) The case of Jeffrey Dahmer: Sexual serial homicide from a neuropsychiatric developmental perspective. Journal of Forensic Science 47(6): 1347-1359.

19. White JH, Lester D, Gentile M, Rosenbleeth J (2011) The utilization of forensic science and criminal profiling for capturing serial killers. Forensic Science International 209(1-3): 160-165.

20. White JH (2007) Evidence of Primary, Secondary, and Collateral Paraphilias Left at Serial Murder and Sex Offender Crime Scenes. Journal of Forensic Sciences Blackwell Publishing Limited 52(5): 1194-1201

21.Zuckerman M (1979) Sensation seeking: Beyond the optimal level of arousal. Erlbaum, Hillsdale.

\section{Your next submission with Juniper Publishers} will reach you the below assets

- Quality Editorial service

- Swift Peer Review

- Reprints availability

- E-prints Service

- Manuscript Podcast for convenient understanding

- Global attainment for your research

- Manuscript accessibility in different formats ( Pdf, E-pub, Full Text, Audio)

- Unceasing customer service

Track the below URL for one-step submission https://juniperpublishers.com/online-submission. 